\title{
ДОПОМОГА ІНОЗЕМНИХ БЛАГОДІЙНИХ ОРГАНІЗАЦЙ У СПРАВІ НАЛАГОДЖЕННЯ ХАРЧУВАННЯ ДІТЕЙ У РОКИ ШТУЧНОГО МАСОВОГО ГОЛОДУ 1921-1923 РР.
}

Анотація: Метою статті $\epsilon$ аналіз ролі іноземних благодійних організацій у справі налагодження харчування голодуючих дітей у роки масового штучного голоду 1921-1923 рр. Виходячи з окресленої мети, проаналізовано в якому обсязі надавалася допомога від іноземних благодійних громадських організацій; з'ясовано обсяги наданої допомоги у справі налагодження дитячого харчування та визначено якість продуктів, які використовувалися для годування дітей $i$ приготування для них ӥжі.

У висновках нашого дослідження, ми довели, що допомога, яка надавалася благодійними й іноземними організаціями охопила лише 15\% голодуючих дітей. Втім вона полегшила напружену ситуацію в Україні.

Ключові слова: масовий штучний голод, діти, харчування, південь України, сурогати

Століття тому країну охопив голод, що забрав життя 3,5 млн. осіб. Голод носив масовий штучний характер, особливо він уразив південь України, де за офіційною статистикою голодувало понад 60\% населення ${ }^{1}$. Білыше половини голодуючих складали діти. Внаслідок масового штучного голоду 1921-1923 рр. ціле покоління українських дітей було зі зламаними долями, втративши здоров'я та можливість повноцінного родинного виховання, що мало негативні пролонговані міжпоколінні наслідки.

Історіографія та джерельна база дослідження. Дослідження подій масового штучного голоду 1921-1923 рр. в Україні, на жаль, є недостатнім. Ми відзначимо потужну дослідницьку роботу О. Мовчан ${ }^{2}$, Г. Єфіменка ${ }^{3}$, С. Кульчицького ${ }^{4}$, Ф. Турченка ${ }^{5}$. В їх працях проаналізовано причини, перебіг і наслідки масового штучного голоду в УСРР. Регіональні

\footnotetext{
* Шугальова Інна Михайлівна - кандидат історичних наук, провідний науковий співробітник Філіалу «Інститут дослідження Голодомору» Національного музею Голодомору-геноциду (Київ, Україна);

ORCID: https://orcid.org/0000-0002-2397-0611; e-mail: Shug_im@ukr.net

${ }^{1}$ Центральний державний архів вищих органів влади та управління України (ЦДАВО України). Ф. 20. Оп. 1. Спр. 7. Арк. 36.

${ }^{2}$ Веселова О., Марочко В., Мовчан О. Голодомори в Україні 1921-1923, 1932-1933, 1946-1947: Злочини проти народу Київ-Нью-Йорк: Вид-во М.П. Коць, 2000. 270 с.; Голод 1921-1923 років в Україні: Зб. документів і матеріалів / Упоряд. О. Мовчан; Відп ред. С. Кульчицький / АН України, Ін-т історії України. Київ: Наук. думка, 1993. 240 с.

${ }^{3}$ Україна радянська. Ілюзії та катастрофи «комуністичного раю» / Заг. ред. Г. Єфіменка; Авт. кол.: Єфіменко Г., Примаченко Я., Юркова О. Харків: Клуб сімейного дозвілля, 2017. 352 с.

${ }^{4}$ Кульчииький С. Комунізм в Україні: перше десятиріччя (1919-1928). Київ: Основи, 1996. 396 с.

${ }^{5}$ Турченко Ф., Турченко Г. Південна Україна: модернізація, світова війна, революція (кінець XIX ст. - 1921 р.): Історичні нариси Київ: Генеза, 2003. 304 с.
} 
аспекти розгортання масового штучного голоду 1921-1923 рр. розкрито у дослідженнях С. Ляха ${ }^{6}$, В. Кириленка ${ }^{7}$ О. Тригуба й Т. Михайловського ${ }^{8}$. Названі науковці здійснили синергетичний аналіз масового штучного голоду на півдні України, дослідивши передумови, причини, розгортання масового штучного голоду, його регіональну специфіку, поведінку місцевих функціонерів в умовах голоду та реакцію й допомогу міжнародної спільноти голодуючим українцям. Останній аспект деталізовано вивчали представники наукової школи М. Шитюка ${ }^{9}$ та О. Тригуба ${ }^{10}$. Аналізу соціальних аномалій в ювенальній політиці у 1920-х рр. присвячено праці Т. Букрєєва ${ }^{11}$, О. Паращевіної ${ }^{12}$, І. Діптан ${ }^{13}$, А. Зінченко ${ }^{14}$.

Незважаючи на наявний історіографічний доробок, поза увагою дослідників залишилися такі питання, як аналіз долі українських дітей, які проживали на територіях охоплених масовим штучним голодом по завершенню роботи іноземних благодійних місій. Українські науковці звертали увагу на ювенальну складову у контексті надання іноземної допомоги голодуючим, на жаль, залишилися відкритими питання, які висвітлюють обсяги та якість харчування дітей у закладах, наспіх створених комуністичними урядовими установами й аспекти, які характеризують морально-психологічні та фізичні наслідки тривалого голодування для дитячого організму.

Метою статmі є аналіз справи налагодження харчування голодуючих дітей у роки масового штучного голоду 1921-1923 рр. Виходячи з окресленої мети, ми спробуємо проаналізувати заходи комуністичного режиму у справі допомоги голодуючим дітям; з'ясувати в якому обсязі надавалася допомога від громадських організацій; встановити обсяги наданої допомоги у справі налагодження дитячого харчування та визначити якість продуктів, які використовувалися для годування дітей і приготування для них їжі.

Ознаки голоду у південноукраїнських губерніях проявлялися вже з літа 1920 р. Проте комуністичний режим вперто ігнорував повідомлення з губерній щодо надскладної продовольчої ситуації. Норми продрозкладки не скорочувалися. Злочинний режим

\footnotetext{
${ }^{6}$ Лsx C. «Жаркое» на п'яту річницю жовтневої революції: деталі воєнно-політичного побуту на Запоріжжі у 1922 році. Наукові праці історичного факультету Запорізького національного університету. 2006. Вип. ХХ. C. $178-183$.

${ }^{7}$ Кириленко В. Голод 1921-1923 років у Південній Україні: дис.... канд. іст. наук: спец. 07.00.01 - Історія України. Миколаїв, 2015. 230 с.

${ }^{8}$ Тригуб О., Михайловський T. Міжнародні гуманітарні організації на Півдні України у 20-х рр. ХХ ст. Миколаїв: Іліон, 2020. 328 с.

${ }^{9}$ Шитюк М., Горбуров К. Миколаївщина в голодних 1921-1923, 1932-1933, 1946-1947 роках. Миколаїв: Вид-во Ірини Гудим, 2007. 156 c.

${ }^{10}$ Тригуб О., Дудар Л. Діяльність АРА на Миколаївщині (1921-1923 рр.). Емінак. 2007. № 2. С. 105-116.

${ }^{11}$ Букрєєв Т. Досвід подолання дитячої безпритульності та бездоглядності на Півдні України в умовах формування радянського тоталітарного режиму. Дис... к. іст. н.: 07.00.01 «Історія України». Херсон-Луцьк, 2019. $329 \mathrm{c}$.

${ }^{12}$ Паращевіна О. Діти і голод 1921-1922 рр. в Україні // Проблеми історії України : факти, судження, пошуки: міжвідом. зб. наук. пр. / відп. ред. С. Кульчицький. Київ: Вид-во Ін-ту історії України, 2005. Вип. 14. С. 137146.

${ }^{13}$ Диптан И. Деятельность чрезвычайных государственных органов борьбы с детской беспризорностью в Украинской ССР (1919-1932 гг.): автореф. дис... канд. ист. наук: 07.00.01 - История Украины. Киев, 1991. 22 с.

${ }^{14}$ Зінченко А. Дитяча безпритульність в радянській Україні в 20-х - першій половині 30-х років XX століття: дис... канд. іст. наук: 07.00.01 - Історія України. Одеса, 2002. 21 с.
} 
ігнорував повідомлення про факти смертей від голоду, канібалізму, трупоїдства в Україні. Більшовицькі вожді воліли помічати голод лише у Поволжі. Українській губернії мали віддати останні запаси на користь голодуючих у Росії. Одночасно, УСРР мала прийняти біженців з РСФРР і забезпечити дітям з голодуючих районів Росії прихисток і відпочинок. В Україну, населення якої було виснажене від голоду, відбувався наплив біженців з Росії, що істотно гальмувало справу налагодження дитячого харчування. Переселення мало як організований урядом характер (наприклад, оголошувалося про пільговий проїзд переселенців залізницею), так і стихійний.

Справою налагодження харчування дітей, що прибували з РСФРР, опікувалася Рада захисту дітей (РДЗ). Вона була створена 10 березня 1919 р. при Наркоматі сощіального забезпечення УСРР. При губвідділах комісаріату діяли місцеві ради. До складу Всеукраїнської РЗД під головуванням наркома соцзабезпечення М. Зубкова увійшли представники комісаріатів освіти, охорони здоров'я, соцзабезпечення, шляхів сполучення і продовольства, від Російського та Українського Червоного Хрестів. Рада мусила забезпечити узгоджену роботу наркоматів та установ з рятування дітей.

Співробітники ради проводили евакуацію дітей 3 голодуючих районів, організовували пункти харчування та ночівлі. Раднарком РСФРР розпочав широкомасштабну евакуацію дітей з центральних губерній до УСРР ще на початку голоду. 8 квітня 1919 р. РЗД Росії звернулась до своїх українських колег з проханням про прийняття 70 тис дітей. У республіці було підготовлено заклади для їх оздоровлення. Зокрема, перша чернігівська колонія прийняла понад тисячу дітей з Петрограду, а літні табори губернії близько 10 тис, на Харківщину було вивезено 1100 дітей з Іваново-Вознесенська, на Київщину направлялися діти з Володимирської губернії. Понад 9 тис. дітлахів з Петрограду та Москви знайшли притулок на Полтавщині, де значну роботу з їх влаштування проводила «Ліга порятунку дітей» - філантропічна організація демократичної інтелігенції, почесним головою якої був В. Короленко.

Згідно умов так званого «офіційного» переселення, в УСРР мало прибути 75 тис. дітей з РСФРР. Проте, як відзначив дослідник В. Кириленко, лише в Одеську та Миколаївську губернії до листопада 1921 р. їх прибуло понад 100 тис., на Херсонщині офіційно зареєстровано 1200 переселених дітей ${ }^{15}$, а стихійне переселення не припинялося й не реєструвалося.

Всі доводи, що українські губернії, особливо їі південні (зернові) райони потерпають від голоду, а населення вмирає від виснаження, замовчувалися місцевими більшовиками й ігнорувалися надісланим з Москви функціонерами.

У 1922 р. приховувати масову смертність українців від голоду вже було неможливо. Найбільше страждали діти. В УСРР голодувало понад 2 млн. дітей. Згідно повідомлень чиновників з органів соціального виховання, майже 700 тис. смертей від голоду. Смертність серед дітей молодшого віку складала 70\%. Лише після оприлюднення статистики щодо голодуючих українців, Кремль дозволив своїм речникам в УСРР Х. Раковському та Ю. Коцюбинському розпочати переговори 3 Місіями Нансена та Американською адміністрацією допомоги (АРА) щодо надання допомоги українцям ${ }^{16}$.

\footnotetext{
${ }^{15}$ Кириленко В. Голод 1921-1923 років у Південній Україні... С. 101.

${ }^{16}$ Голодомори на Запоріжжі 1921-1923 pp., 1932-1933 pp., 1946-1947 pp. «Спокута»: альманах № 8-9. Запоріжжя: Дніпровський металург, 2008. 520 с., док. 24.
} 
3 весни 1922 р. зусиллями АРА на території Запорізької губернії було розгорнуто так звані американські кухні, що забезпечили харчування 75 тис. маленьких запоріжан ${ }^{17}$. В Одесі, зусиллями АРА організовано 16 їдалень на 22313 дітей ${ }^{18}$. у Київській, Волинській і Подільській губерніях АРА годувала 12 тис. дітей. Їдальні працювали шість днів на тиждень. До раціону входили какао, солодке молоко, жири ${ }^{19}$. Часто на обід подавалися страви з рису, пшона, проса, бобових. Картопля та м'ясо до раціону включалися вкрай рідко. Частина продовольства імпортувалася, решта закуповувалася на місцевих базарах. Тобто, акцент благодійників у харчуванні робився на поживності раціону, а не на його збалансованості. Тут могли бути численні хиби, оскільки виснажені голодом дитячі організми часто фізично не були здатні приймати таку насичену ліпідами та вуглеводами їжу.

Враховуючи поліетнічність південноукраїнських губерній, допомога дітям надавалася зусиллями благодійних організацій менонітів (для німецьких колоній Хортиця, Ейнлаге, Шенвізе, Розенталь, Пришиб, Францівка й ін.); чехів (для населення колонії Чехоград на Мелітопольщині та у Криму), «Джойнт» для єврейського населення, Червоного Хреста. Наприкінці травня 1922 р. вищеназвані організації надали Запорізькій губернії допомоги у вигляді продовольчих пайків. Від АРА надійшло 85 тис пайків, від Чехословацького Червоного Хреста 10 тис., від менонітів - 15 тис. Місія «Джойнт» розгорнула 3 кухні в Одеській губернії. У жовтні 1922 p. забезпечила 1250 пайками голодуючих дітей; у квітні 1923 р. відкрито їдальні при школах у Захарівці (Одещина) на 100 малят та у Тирасполі - на 200. 3 осені 1922 р. «Джойнт» намагався надати продовольчу та медичну допомогу дитячим притулкам Херсонщини та Миколаївщини. Проте допомога іноземних благодійників носила періодичний несистемний характер. Наприклад, АРА надавала допомогу голодуючим запорізьким малятам лише протягом одного місяцяя 20 . А Всесвітня Єврейська Конференція Допомоги «Вереліф» надавала лише локальну підтримку, створивши дієтичні їдальні у с. Дальнику для 350-600 дітей, у м. Ананьєв на 1500 дітей і видавши 500 продовольчих пайків у с. Татарці.

Широкомасштабну допомогу розгорнуло Всеукраїнське Товариство Червоного Хреста $^{21}$. Члени Червоного Хреста у Запорізькому краї у листопаді 1922 р. відкрили 81 харчовий пункт, де годували 7667 дітей 22.

Відсоток дитячої смертності від голоду та його наслідків систематично зростав. Більшовицькі функціонери переконували, що на потреби голодуючих дітей виділено 50\% продовольчих надходжень (це становило близько 5 тис. пудів продовольства). Цієї допомоги могло вистачити на 33 тис. голодуючих дітей. У той же час лише у Запорізькій губернії голодувало 489281 дитина (із загальної кількості 502121 дітей) ${ }^{23}$.

Центральний (Харківський) уряд прийняв рішення розв'язати справу налагодження проблем харчування дітей за рахунок передачі голодних дітей на патронат. Дітей

\footnotetext{
${ }^{17}$ Сербин Р. Голод 1921-1923 і українська преса в Канаді. Торонто-Київ: Українсько-Канадський ДослідноДокументаційний Центр; Інститут української археографії Академії наук України, 1992. С. 613.

${ }^{18}$ ЦДАВО України. Ф. 20. Оп. 1. Спр. 8. Арк. 71.

${ }^{19}$ Голодомори на Запоріжжі 1921-1923 рр., 1932-1933 рр., 1946-1947 pp.... док. 69.

${ }^{20}$ Голодомори на Запоріжжі 1921-1923 pp, 1932-1933 pp., 1946-1947 pp....

${ }^{21}$ До «Тижня Українського Червоного Хреста» // Селянська-Робітнича правда. 1924. 11 травня.

${ }^{22}$ Боротьба з наслідками голоду. Становище на Запоріжжі // Вісти ВУЦВК. 1922. 21 листопада.

${ }^{23}$ Державний архів Запорізької області (ДАЗО). Ф. Р-28. Оп. 2. Спр. 16. Арк. 2-2зв.
} 
передавали до селянських виробничих обєднань (ТСОЗів, колгоспів, артілей) на виховання й утримання. Селяни, обтяжені голодом і постійними вимогами комуністів збільшити норми хлібозаготівель, неохоче погоджувалися на патронування. Проте, лише на Катеринославщині було передано на патронат до Кременчуцької губернії 5 тис. малят.

Нагадаємо, ще у 1919 р. В. Леніним було підписано Декрет «Про безкоштовне дитяче харчування», який гарантував дітям віком до 14 років безоплатне харчування, в незалежності від того, до якої категорії пайки належали їх батьки (це було пов'язано із картковою системою). У роки штучного масового голоду 1921-1923 рр. цей декрет ніхто не скасовував. Він продовжував діяти, але достатньо умовно. Зусиллями Катеринославської губернської ради захисту дітей було розгорнуто мережу їдалень для дітей. Зокрема, у Катеринославській губернії в їдальні харчувалося 2 тис. дітей (із 108279 загальної кількості голодуючих дітей $)^{24}$. Загалом, у цій губернії було відкрито 119 їдалень, де харчувалося 14294 дітей, а 120515 малят залишилися поза державним забезпеченням харчами ${ }^{25}$. у Запорізькій губернії у державних їдальнях отримували обіди лише 67223 дитини, а 422068 малят опинилися поза увагою держави ${ }^{26}$.

До того, урядова допомога голодуючим дітям здійснювалася диференційовано. До державної їдальні, насамперед, приписувалися діти, віком до 5 років ${ }^{27}$, хворі та слабкі діти, переселені з Росії ${ }^{28}$, потім - від 5 до 16 років. Інспектори РЗД наполягали, щоб діти отримували гарячу їжу не пізніше 10 години ранку, проте на практиці це виконувалося не завжди.

Якість харчування дітей у їдальнях була вкрай незадовільною. Катеринославський губернський виконавчий комітет повідомляв, що спроможний надати гарячі обіди лише 15\% дітей губернії. Гарячий обід складався $3 \frac{1}{4}$ фунта звареної макухи та $1 / 2$ фунта хліба. Хліб також був із макухи ${ }^{29}$. Якість хліба була вкрай незадовільною. У Запорізькій губернії було обстежено дитячі їдальні та проведено хімічний аналіз складу продуктів. Хліб виявився тугим важким коржиком із гіркуватим присмаком. Хімічний аналіз виявив значну кількість клітковини, крохмальні зерна змішаної природи, жирові тільця, пил і забруднення. Загальний висновок експертизи якості хліба засвідчив, що борошно, з якого пекли хліб, було низькопробним і зіпсованим, крім того у хлібі знайшли значну частину домішок, золи, клітковини та лушпиння ${ }^{30}$. Проте навіть сурогатного хліба не вистачало: запорізький губвиконком повідомляв про катастрофічне становище із забезпеченням продуктами харчування дитячих закладів і відсутністю у губернії зернохліба ${ }^{31}$.

Низька якість харчування була визнана навіть більшовицькими функціонерами. Офіційний речник КП(б)У - газета «Білышовик» 4 січня 1922 р. опублікувала замітку, де констатувала, що у відносно благополучній Миколаївській губернії повсюдно вживаються сурогати. Так само на офіційному рівні було визнано, що на Запоріжчині в їжу вживаються

\footnotetext{
${ }^{24}$ ЦДАВО України. Ф. 20. Оп. 1. Спр. 7. Арк. 36.

${ }^{25}$ ЦДАВО України. Ф. 20. Оп. 1. Спр. 7. Арк. 60.

${ }^{26}$ ДАЗО. Ф. Р-28. Оп. 2. Спр. 16. Арк. 2-2зв.

${ }^{27}$ ЦДАВО України. Ф. 20. Оп. 1. Спр. 7. Арк. 72.

${ }^{28}$ ЦДАВО України. Ф. 20. Оп. 1. Спр. 12. Арк. 53.

${ }^{29}$ ЦДАВО України. Ф. 20. Оп. 1. Спр. 8. Арк. 56.

${ }^{30}$ ДАЗО. Ф. Р-2. Оп. 4. Спр. 6. Арк. 131.

${ }^{31}$ Голодомори на Запоріжжі 1921-1923 pp, 1932-1933 рр., 1946-1947 рр.... док. 42.
} 
домішки макухи, кураю, лебеди, кукурудзи, рогози, листя дерев. Зазвичай домішки становили 60-75\% звареної їжі, але все частіше фіксувалося 100\% вживання в їжу сурогатів $^{32}$. Сучасний дослідник штучного масового голоду 1921 р. В. Кириленко зауважував, що окрім собак, кішок, падалі, копит тварин (холодець), на Херсонщині «готували» «іжака», дерть та яшну, на Одещині - в їжу йшло зіпсоване насіння льону, яке перетирали у дерть і подрібнені у порох кукурудзяні листя ${ }^{33}$.

Поживність харчування для дітей обмежувалася 993 калоріями. До раціону входили: хліб - 21 золотник (зол. = 4,27 г.); м'ясо - 1 зол.; крупа - 4 зол.; жири - 3 зол. ${ }^{34}$ ЦК Помдит визнавала, що харчування дітей (особливо у дитячих притулках) не є дієтичним; діти отримували недостатню кількість овочів і м'яса, що незадовільно впливало на стан їх здоров'я.

Отже, поживність державного харчування була низькою, що відбивалося на здоров'ї дітей. Нагадаємо, що санітарні норми харчування на добу для дитини віком від 1 до 10 років передбачали: 10 г. житнього та 40 г. пшеничного хліба (для дітей 5-6 років - 40 та 120 г. відповідно, а для дітей віком 7-10 років - 75 г. житнього та 165 г. пшеничного), круп 20-30 г. (для різних вікових категорій), макарони - по 10 г., м'яса 50-70 г. для дітей віком 1-2 років, та 100-140 г. - для дітей від 3 до 10 років, риби - від 20 до 60 г., цукру від 40 до 75 г. Це тільки окремі позиції денного раціону дитини. Загалом повноцінне добове харчування дитини віком до 10 років включає пшеничне борошно (від 5 до 20 г.), крохмаль, 1-2 яйця, сир (40 г.), сметану та вершки (5-15 г.), твердий сир, 15-25 г. тваринні та 2-7 г. рослинні жири, картоплю (100-200 г.), овочі (150-275 г.) фрукти (150-200 г.), ягоди (20-40 г.).

Висновки. Висновки нашого дослідження базуються на матеріалах Державного архіву Запорізької області та Центрального державного архіву вищих органів влади та управління. Справа налагодження дитячого харчування в роки масового штучного голоду зазнала фіаско. Допомога, що надавалася благодійними та іноземними організаціями охопила лише 15\% голодуючих дітей і носила несистемний вибірковий та періодичний характер (короткотривалість термінів роботи кухонь, локальність їх розташування, вибірковість охопленого допомогою контингенту, при цьому вибірка здійснювалася як правило, за національною ознакою, що часто залишало українських дітей поза увагою іноземних благодійників. Втім благодійна допомога певною мірою полегшила напружену ситуацію в Україні. У той же час комуністичний тоталітарний режим, який фактично став організатором масового штучного голоду 1921-1923 pp., у справі налагодження дитячого харчування реалізовував украй суперечливі та малорезультативні заходи, основна суть яких зводилася до передачі голодуючих дітей на патронат до селянських родин. Харчування для дітей, організоване державними губернськими установами, відзначалося скудністю раціону, низьким рівнем поживності меню та незадовільною якістю продуктів, з яких готували так звані обіди для малят.

Результатом такого ставлення уряду до українських дітей стало повсюдне вживання в їжу сурогатів, що негативно позначалося на здоров'ї дітей. Спостерігалися соматичні зміни органів травлення, загальмовувалося зростання організму дитини, об’єми грудної клітини

\footnotetext{
${ }^{32}$ ЦДАВО України. Ф. 20. Оп. 1. Спр. 8. Арк. 25зв.

${ }^{33}$ Кириленко В. Голод 1921-1923 років у Південній Україні... С. 93.

${ }^{34}$ ЦДАВО України. Ф. 20. Оп. 1. Спр. 12. Арк. 87.
} 
та черепу, як правило, не відповідали віковим вимогам 3 медичної точки зору. Порушувалися фізіологічні, психічні, пізнавальні, вольові процеси дитячих організмів. На жаль, комуністичний тоталітарний режим не був зацікавлений у вихованні здорової нації. До дітей, як і до людей взагалі, ставилися лише як до гвинтиків системи, метою якої було захоплення влади над територіями та контролю над людьми.

Inna Shugalyova

\section{Assistance of Foreign Charity Organizations in Adjusting Child Nutrition in the Years of Artificial Mass Famine of 1921-1923}

Abstract: The purpose of our article is to analyze the process of organizing children's nutrition during the years of massive artificial famine in 1921-1923. Based on the intended goal, we will try to analyze the measures of the communist regime in providing assistance to starving children; find out to what extent assistance was provided from public organizations; Let's characterize the quality of the products that were used for children.

The conclusions of our research are based on the materials of the State Archives of the Zaporozhye region and the Central State Archives of the highest authorities and administration. The process of organizing children's nutrition during the years of massive artificial starvation turned out to be unsatisfactory. Aid provided by charities and organizations reached only $15 \%$ of starving children and was ad hoc, selective and periodic. However, charitable assistance to a certain extent eased the tense situation in Ukraine. At the same time, the communist regime, which actually became the organizer of the massive artificial famine of 1921-1923, implemented extremely contradictory and ineffective measures, the main essence of which was to transfer starving children to peasant families for patronage. Food for children, organized by government agencies, was characterized by a paucity of diets, a low level of nutritional value of the menu and unsatisfactory quality of food from which meals were prepared.

The result of this attitude of the government towards Ukrainian children were the widespread use of surrogates in food, which negatively affected the health of children. Somatic changes in the digestive organs were observed, the growth of the child's body slowed down, the volumes of the chest and skull, as a rule, did not meet the age requirements from a medical point of view. The physiological, mental, cognitive, volitional processes of children's organisms were violated. Unfortunately, the communist regime was not interested in bringing up a healthy nation. Children, like people in general, were treated only as components of a system whose purpose was to seize power over territories and establish control over people.

Keywords: Mass artificial famine, children, food, southern Ukraine, surrogates 